\title{
An Exploratory Study into Menstrual Hygiene Management amongst Rural High School for Girls in the North West Province, South Africa
}

\author{
Bornwell Chishala Chikulo \\ Department of Development Studies \& \\ Research Focus Area 'Population \& Health' \\ North West University, Mafikeng Campus \\ Tel Number: + 2718389 2249; Fax Number: + 27183892504 \\ E-mail:bornwell.chikulo@nwu.ac.za
}

\section{Abstract}

Menstruation remains a taboo subject and presents many challenges to girl learners in South Africa. Cultural taboos about menstruation also have a negative impact on the dignity, school participation and health of girl learners. This study explores the menstrual hygiene practices and knowledge of girls at 10 rural government high schools in the North West Province. The study focuses on themes related to knowledge, practices, beliefs, and challenges related to menstrual hygiene management (MHM) and the use of the menstrual cup. The findings identified a knowledge deficit on MHM amongst girl learners between the knowledge base of girls and the information reportedly taught in schools by educators and passed on by parents. The inadequate toilet facilities and knowledge deficit on MHM contributes to school absenteeism.

Keywords: Menstrual Hygiene Management (MHM), Menses, Menstruation, Menstruation cup, Sanitation, WASH

\section{Résumé}

Une étude exploratoire de la gestion de l' hygiène menstruel parmi les filles provenant des milieu hautement rural dans la Province du Nord-Ouest, Afrique du Sud. La menstruation chez la fille reste un sujet tabou et présente de nombreux défis pour le les élèves en Afrique du Sud. Les tabous culturels à propos des menstruations ont également un impact négatif sur la dignité, la frequantation scolaire et la santé des filles. Cette étude examine les pratiques d'hygiène menstruels et les connaissances des jeunes filles de 10 écoles publiques rurales élevées dans la Province du Nord-Ouest. L'étude se concentre sur des thèmes liés aux connaissances, les pratiques, les croyances et les défis liés à MHM et 
l'utilisation de la coupelle menstruelle. Les résultats ont identifié un déficit de connaissances sur MHM parmi les filles apprenants entre autre la base de connaissances des filles et les informations auraient enseigné dans les écoles par les enseignants et transmises par les parents. L'insuffisance des installations sanitaires et déficit des connaissances MHM contribue à l'absentéisme scolaire.

Mots-clés:

\section{Introduction}

Menstruation hygiene management (MHM) refers to the personal hygiene during menstruation which comprises the bathing, the use of clean, dry sanitary material and disposal of used material in a clean environmentally acceptable and safe manner (Glaas, 2010;WSCC 20I3;UNICEF 20I2b).A holistic definition of MHM emphasises three essential dimensions as follows (WHO/UNICEF , 20|3:3):

i. articulation, awareness, information and confidence to manage menstruation with safety and dignity using safe hygiene materials together with

ii. adequate water and agents and spaces for washing and bathing and

iii. disposal with privacy and dignity."

Effective MHM requires the combination of all three dimensions listed above.. MHM affects $52 \%$ of the female population (i.e. $26 \%$ of the world's population) who are of reproductive age at any one time and who each month experience menstrual cycle for up to 52 days per year (McMahon et al., 201I; Water Aid, 2009).

Menstruation is thus defined as the regular and biological process of the discharge of blood from the uterus which the majority of the girls and women face. Girls normally begin their menstrual periods between the ages of 10 and 14 and this continues until they reach menopause usually between their late forties to midfifties (Nahar \& Amed 2006). Menstruation is associated with puberty. It is one of the physiological and maturation changes that take place during puberty. During adolescence a girl's body starts to undergo physical changes. This entails developing breasts, wider hips, and body hair and the girl also undergoes emotional changes due to hormones. The cycle for the menstrual period normally takes around 28 days, but can vary from 2l -35 days (Nahar \& Amed 2006). Menstruation if it is not managed effectively can interfere with the girl learners school attendance and participation (McMahon et al., 20I I; Ali \& Rizvi, 20I0).

MHM has emerged as a world-wide health issue in recent years due to its importance to the health, well-being, human rights and achievement of the Millennium Development Goals concerning women and girls. Scholarly articles indicate that effective MHM can facilitate the achievement of MDG 2 (achieve universal primary education) and MDG 3 (promote gender equity and empower women) (EEPA, 2007: Jasper, Le 
\& Bartram 2012; WaterAid, 20I2;WHO/UNICEF, 20I3).

However, until recently, MHM has remained a neglected issue that has been overlooked in adolescent and sexuality programmes. As a consequence, the impact of MHM on girl learners remains a relatively new area of research (UNFPA, 2000). The reason why MHM has previously been neglected could be attributed to the "culture of silence "on the topic where menstruation is seen as a "secret" (Sommer, 20I I). As the European External Policy Advisor (EEP2007:6) report indicates :"menstrual blood and menstrual hygiene" concerning reproductive health, sexuality and all related issues is considered almost everywhere as a "no-go" area." The continued silence and taboo, surrounding the issue of menstruation coupled with limited access to information and knowledge about MHM at home and in schools results in millions of girl learners having inadequate knowledge about what is happening to their bodies when they menstruate and how to deal with it effectively. Inadequate information, misconceptions and negative attitudes to menstruation may lead to poor menstrual hygiene practices, as well as to a negative self-image among adolescent girls (Nagar \& Aimol, 20ll; Shanbhag et al., 2012; WaterAid, 2009).

Numerous qualitative studies have identified a lack of MHM education programmes as the main reason for missed school days and demonstrated that some improvement in MHM and knowledge based on educational interventions may improve school attendance (Montgomery, Ryus \& Dolan, 2012). Studies in most developing countries have also shown that girls prefer avoiding school during their monthly menses rather than to experience embarrassment related to menstrual mishaps (Dasgupta \& Sarkar, 2008; Montgomery, Ryus, Dolan, Dopson \& Scott, 20I2). As a result, studies confirm that the onset of puberty leads to significant changes in school participation among girls (UNICEF, 2005; GAPS \& FAWE Uganda, 1999).

In Africa, approximately I in 10 girl learners do not attend school during menstruation for 4 days every month or drop out at puberty because of the lack of clean and private sanitation facilities in school (UNICEF, 2005; World Bank, 2005)'.

In east and southern Africa, studies indicates that some $70 \%$ of girl learners miss one to three school days a month due to menstruation - leading to decreased participation in school activities and high drop-out rates (SVN 20I5).

In South Africa, research by Save the Children and various United Nations Agencies (Save the Children 20I5; UNICEF,20I0; WaterAid, 2009;WHO,2010) indicates that girl learners miss school for a few days each month because of menstrual related problems and, in some cases, often drop out of school. This is especially the case for girl learners coming from poor settings. It is estimated that about $30 \%$ of girl learners miss classes at school during their menses, most likely due to the fact that about $60 \%$ of South African women lack access to proper MHM (WRC, 20II). As a result, many girl learners miss approximately one week of school per month whilst they are menstruating. This equates to about 4 days 
per month lost, which can add up to 528 days of schooling across the years that a girl learner should be in school (DWCPD, 20I3). In short, girl learners miss a quarter of their school education due to their menses.

Furthermore, the issue of MHM has long been under-discussed. The silence and stigma associated with menstruation combined with limited access to information at home and school about what happens to the bodies when they menstruate and how to deal with it, disadvantages the girl learners at school. This state of affairs has the potential to undermine efforts to keep the girl child in school for the entire stipulated learning time. It also has the potential to undermine the achievement of MDG goals 2 and 3 (Kaiser 2005; Udjo and Lalthapersad-Pillay, 2015). This raises challenges for girl learners in terms of MHM, as well as dignity and confidence to be active members of society.

\section{Transnet Teenage Health Programm}

The ability of women and girls to have access to MHM knowledge and education is a universally neglected issue mainly due to myths, misconceptions and taboos concerning menstruation. Menstruation is normally considered to be "impure" ,"dirty" ,"polluted" and no-go" area." (EEPA, 2007; WaterAid, 2009).

In order to empower girl learners at rural high schools in the North West Province, the Transnet Foundation Health, has introduced intervention programmes to improve the MHM education, knowledge and practices, To position itself as a caring corporate citizen, Transnet, through its company social investment arm, the Transnet Foundation, launched the Teenage Health Programme that provides education, awareness and female hygiene products to the poorest, mainly rural communities of South Africa. In these communities, where some households get minimal or no income at all, and poverty forces them to live with the bare necessities, menstrual hygiene has been moved to the bottom of the household priority list. As a result, in such communities, there are girls and women who are battling to maintain their dignity and self-esteem. The Transnet Teenage Health Programme seeks to make a contribution to better MHM through promoting better awareness, education, and sensitization of girl learners to the essentials of good MHM. The Teenage Health Programme (TTHP) seeks to give young girls a future through education by:

$e$ in the North West Province

- Minimizing the school absenteeism and dropout rates for girls;

- Enabling girls to participate fully in social and academic activities;

- Teaching girls to maintain basic good, clean feminine health and hygiene practices;

- Improve young girls' quality of life.

In short, the program seeks to enable adolescent girls in South Africa's poorest communities to embrace their femininity, improve confidence and self-respect. Furthermore, Transnet Foundation Health through its TTHP seeks to promote sustainable, environmentally - friendly methods of managing menses. In the TTHP the girl learners are being encouraged to move away from the traditional approach of managing menses such as the use of 
cloth, newspapers, sanitary pads, tampons and toilet tissue, towards a single product that is reusable, sustainable and can be used for many years. To this end, the TTHP seeks to promote the use of the menstrual cup. In addition, the TTHP seek to make learners to be proud as girls and give them the dignity, self-esteem and confidence they need to be active members of their society.

This study was conducted at 10 high schools in the North-West Province of South Africa where Transnet Foundation has been implementing its TTHP. The schools were selected from schools in Quintile I \& 2 of the Department of Education and Sports in the North West Province. This means that the selected schools were located in poor rural areas or their recruitment (catchment) areas are located in poor rural localities.

\section{Methods}

A descriptive study with mixed methods (quantitative and qualitative) was applied. The qualitative method entailed examination and interpretation of data collected primarily through observations, interviews and focus group discussions, This approach provides the base for a more descriptive, interpretive and thematic analysis that facilitates ways of understanding human phenomena within the context in which they occur. The quantitative approach, on the other hand, involves the numerical manipulation of observations for the purpose of describing and explaining phenomena. Thus the two approaches complement each other: the qualitative approach provides "insight" to data, while the quantitative approach reduces complex situations to "statistics" (Yates, 2004). Evidence was collected from the following and triangulated to inform the evaluation of findings. A survey of adolescent girl learners from Grade 10 and II in selected government high schools in the North West Province, South Africa, was conducted using a self-administered structured close-ended individual questionnaire.

A total of 1,018 girl learners participated in the survey (ID/s). The sample included all Grade 10, I I and I 2 girl learners aged between 13 and 22, from poor background, who participated in the TTHP 2013.

In addition, a semi-structured FGD guide was used in conducting 10 Focus Group discussions (FGD); involving about 150 girl learners were conducted. One Focus Group discussions (FGD) was conducted at each school. Each Focus Group consisted of 15 girl learners. The objective was to provide girl learners with the opportunity to discuss their MHM experiences in small groups led by facilitators from Moropa Development Services, who had been working with the learners in the TTHP. Informal interviews with life orientation (LO) educators and principals of the schools were also conducted at the 10 high schools.

\section{Objectives of the study}

The aim of the study was to:

- determine the perception of MHM of school girl learners;

- determine the common MHM practices among girl learners;

- determine the impact of menstruation on school participation; and 
- make recommendations on how to improve MHM for girl learners at the school.

Overall, study is designed to provide insight into the girl learners' attitudes and practices towards menstruation and MHM.

\section{Results and discussions}

The ages of the respondents varied from 15-22 years old. The oldest girl learners were found at rural farm schools. The mean age of respondents surveyed was I7.I years.

Knowledge and Understanding of Menstruation

The findings indicate that the majority of girl learners participating in the study had prior knowledge about menstruation before their first menarche. The survey identified that mother $(55.2 \%)$, sisters (14.1\%), grandmother ( $12.1 \%)$, auntie $(7 \%)$ and friend $(6 \%)$ as the main source of information about menstruation. More significantly, no respondents reported receiving any information on menstruation from educators. However, many participants in FGD reported that the educators, especially male Life Orientation (LO) educators, were usually uncomfortable discussing issues on menstruation and reproductive health. Discussions with LO educators also indicated that educators lack information and training on issues of menstruation, MHM, reproductive health and sexuality.

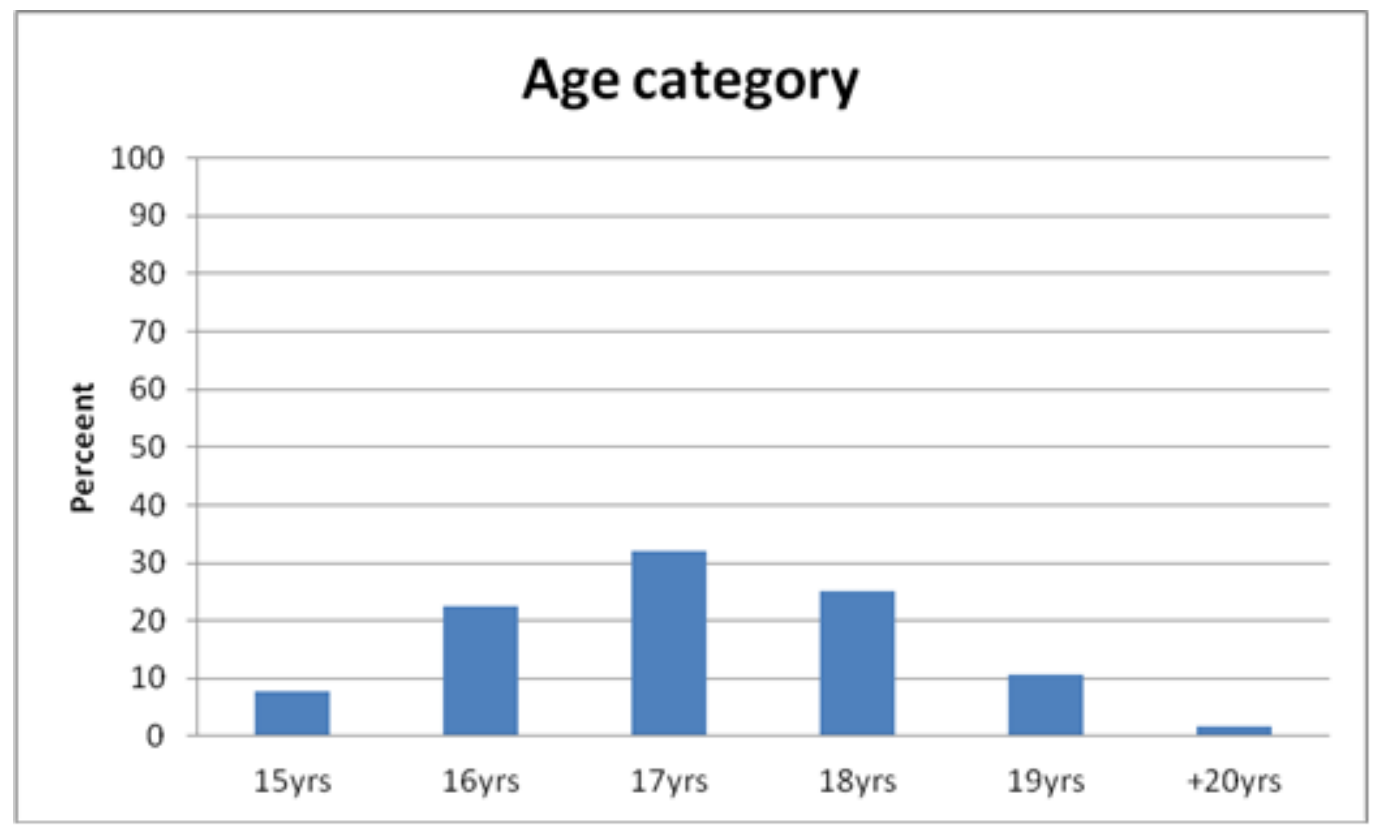

Figure I: Breakdown of Ages of Respondents 


\section{Where did you first receive information regarding menstruation?}

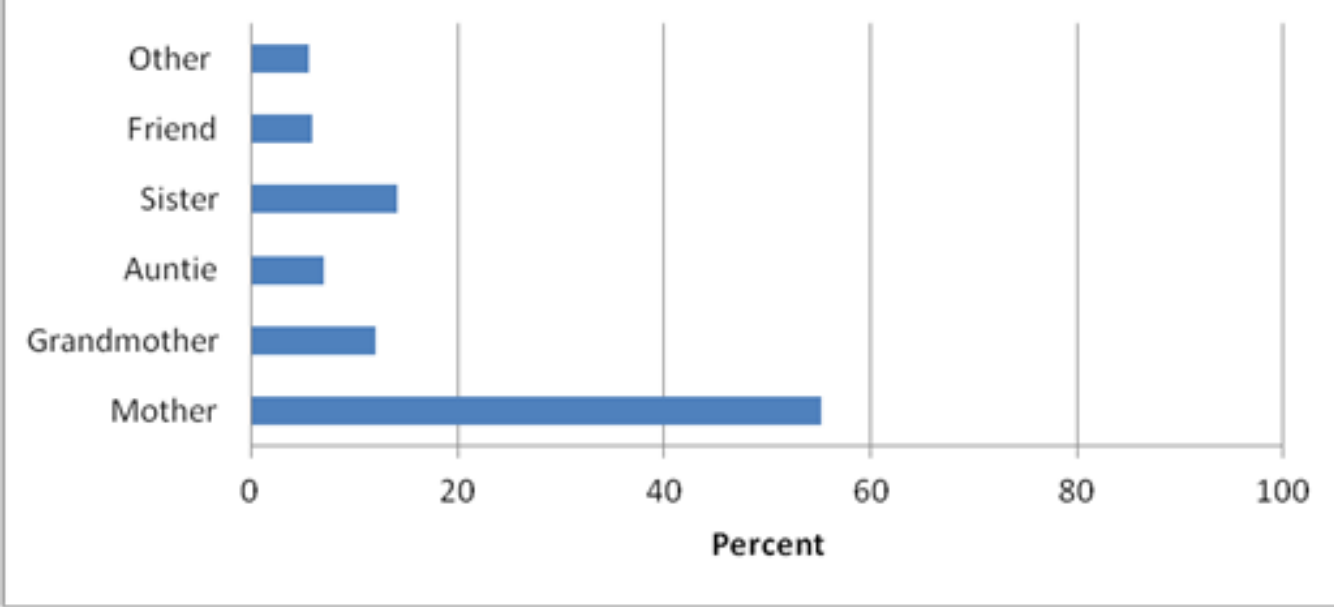

Figure 2 Source of First Information on Menstruation

There is a general lack of information and knowledge on menstruation amongst girl learners. While the majority of the participants had heard about menstruation before their menarche, not much detail was provided to them concerning the biological basis of menstruation, how to manage menses and how to dispose of used sanitary material properly.

Furthermore, the information received is often selective and tainted by myths, negative perceptions and taboos. As a result, most, participants had little understanding of what was happening to their bodies each month, and did not have the opportunity to talk, ask questions and learn prior to the TTHP intervention.

There is a lack of educational material on MHM available in schools. In addition, most educators do not only lack knowledge about menstruation and the girl learners' menstrual needs and are reluctant to engage with this issue, but do not consider MHM an important subject. As a result, many girl learners encounter their menarche unprepared.

The lack of information and knowledge on menstruation together with the negative attitudes to menstruation, in some cases also result in a negative self-image and a lack of confidence and self-esteem amongst girls.

The results of this study are thus consistent with the findings on MHM in studies conducted elsewhere. Studies conducted elsewhere have also shown, to varying degrees, that mothers are an important source of information on menstruation for the adolescent girls (Dasgupta \& Sarkar, 2008; El-Gilany et al., 
2005). However, information on menstruation given by mothers, and other female relations such as grandmother, aunties and sisters, etc., is often lacking in detail and is somewhat incorrect, usually being based on cultural myths, misconceptions and taboos.(Kaiser 2005). It therefore more often than not, encourages negative perceptions and practices of menstruation (Adinma \& Adinma, 2008). Similarly, educators' reluctance to fully handle sensitive topics on menstruation, MHM, reproductive health and sexuality issues have also been reported in studies conducted in Tanzania, India and Malawi (Sommer, 2009; Drakshayani, \& Venkata, 1994).

\section{Cultural Beliefs and Taboos surrounding Menstruation}

Cultural beliefs, myths and taboo in some instances lead to forced seclusion, exclusion and stigma. Only a minority of respondents $(39.3 \%)$ reported some restrictions or exclusion being placed on them during their menstruation at home. Thus a significant per cent of respondents are still subjected to cultural beliefs, myths and taboos relating to menstruation which entail some restrictions and control placed over them and restrict their mobility and behaviour.

Since menstruation in most communities is still considered to be a dirty and polluting, girls having their menses are often considered 'dirty' or 'impure' and restricted from participating in a number of activities such as: cooking, touching food and livestock, socializing, and attending religious ceremonies. However, while, the beliefs related to restrictions were common in almost all communities, the reasons behind the restrictions and exclusion were often unknown nor explained to the girls.

These practices and restrictions reported in this study are consistent with findings in studies undertaken in southern Africa (Kuper, 1982; Ten, 2007), east and central Africa, and the Indian sub-continent (Dasgupta \& Sarkar, 2008; Keerti et al., 201I; McMohon, 20II; Piper-Pilliteri, 2011; Sommer, 2010). These studies indicate that the practice of rituals and seclusion during menstruation, though varied, are practiced across different religious groups and cultures.

However, as this study has established, the cultural practices and rituals do not necessarily equip the girls upon attainment of menarche with the proper and adequate information to effectively manage menstruation and related problems.

\section{Material used to Manage Menstruation}

Disposable sanitary towels (pads) are the most frequently used methods of managing menstruation amongst the girl learners. The majority of the respondents use pads to manage their menstruation (60\%), followed by the M-Cup (35.7\%), and tampons ( $1.9 \%)$. The other methods ranged from using old newspapers, strips of cloths, toilet paper and towels. Even those respondents who reported using pads indicated that when short of money to purchase pads, they resorted to using newspapers, toilet paper, old pieces of cloth etc. However, these methods of managing menses are not only ineffective and uncomfortable, but can also result in serious health problems. 


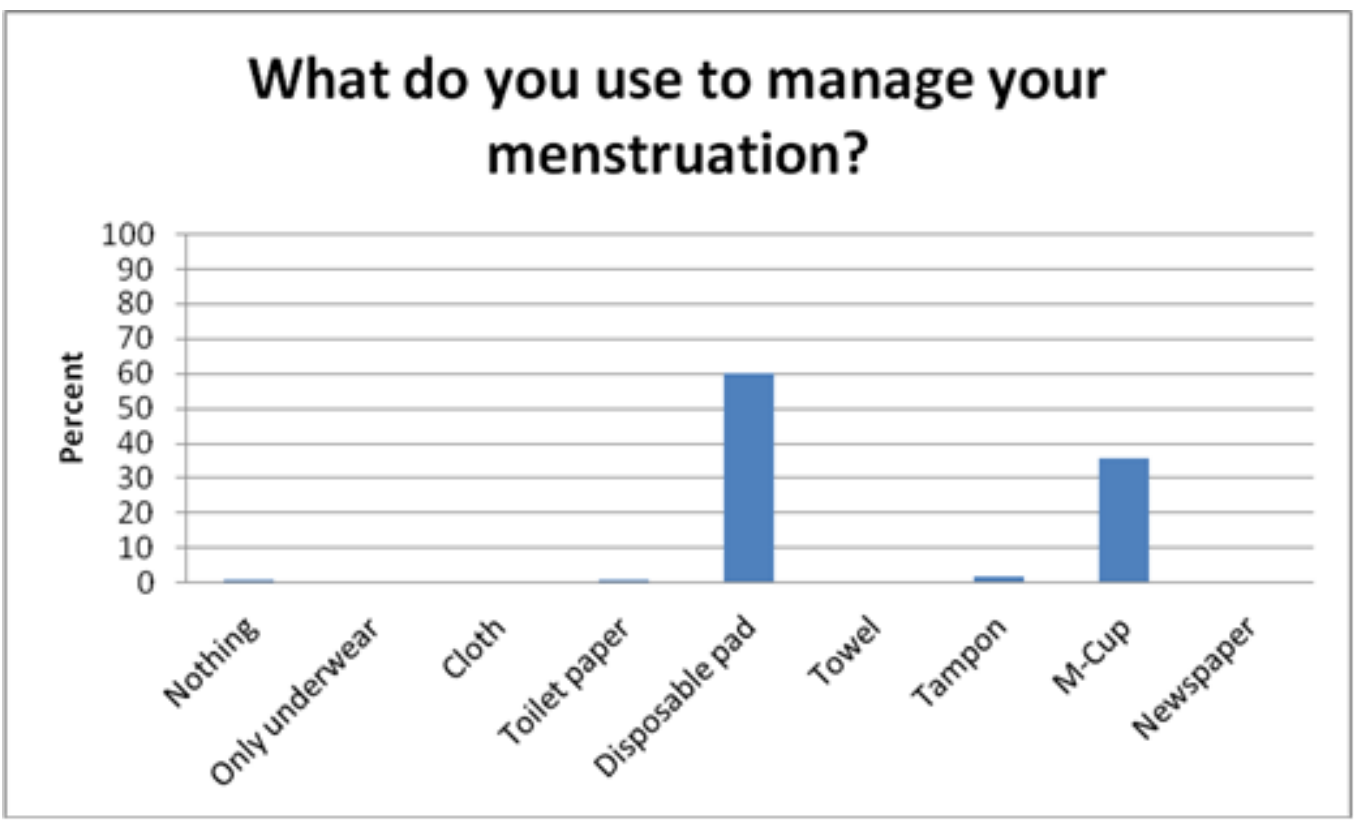

Figure 3: Material Used to Manage Menstruation

During the FGDs, some participants stressed that although sanitary pads are the most frequently used methods of managing menstruation; they are often prohibitively expensive which presents a challenge for poor households. The average cost of a $\mathrm{pad} / \mathrm{tampon}$ is RI.50; the average girl/woman uses about 25 sanitary products during one menstruation period, which amounts to R37.50 per month and R450 per year (Sangonet, 2013). As a consequence, from time to time, some poor families cannot afford to buy the pads, and girls are thus forced to resort to using strips of old cloth and other unhygienic methods such as old newspapers and toilet paper.
At some schools the LO educators and principals reported that a significant number of learners use strips of cloth ,newspapers and tissue but are embarrassed to admit this. Similarly, in FDGs a number of participants admitted to using these items. This means that the use of these unhealthy materials has been under reported because the girls are embarrassed to admit using these unhealthy products. The findings of this study are consistent with the findings in studies conducted in Kenya, Malawi, Nigeria, Tanzania and Uganda (AbioyeKuteyi, 2000; Adinma \& Adinma, 2008; Mc Mahon et al., 20II; Pillitteri, 20II; Sommer, 2009).

Furthermore, in FGDs the participants stated that the cost of sanitary pads is a 
significant issue in their households. Some participants stated that their parents have to struggle to find money to buy disposable pads and that in some months they are unable to do so. This is also similar to findings in Kenya, Tanzania and Uganda (Croft \& Fischer, 2012; Mc Mahon, 20II; Sommer, 2009).In order to overcome the challenges, associated with the use of pads and tampons, TTHP is promoting the use of menstrual cup, as a sustainable solution to MHM in rural areas.

\section{General Hygiene}

In general hygiene practices of the girl learners surveyed were found to be satisfactory. In the survey, $96.5 \%$ reported that they bathed during their menstruation. The majority of the respondents bathed at least twice a day and $27.8 \%$ took a bath more than twice a day. In FGDs participants explained that during their menstruation period, on average they had three baths: one bath in the morning, another after school and the last one in the evening. Furthermore, the majority of the respondents reported that on average they changed their sanitary pads three times per day.

\section{Disposal of Sanitary Material}

Good MHM should obviously include the disposal of used sanitary material. In this study, the majority of the respondents (53.5\%) reported that they throw their dirty sanitary protection material in the toilet and $42.7 \%$ reported that they throw it away in the dustbin. The findings of this study therefore corroborate studies undertaken elsewhere, which indicate that women and girls normally dispose their used sanitary material in the field, river or garbage dump due mainly to a lack of appropriate disposal facilities (Kaiser, 2005; Ten, 2007). Neglecting to provide disposal facilities at schools for used sanitary material, more often results in blocked toilets or latrines becoming quickly filled up (House et al., 20I2).

In the FGDs many participants stated that they wrap their soiled sanitary material in plastic and carry it home to dispose of it in the dustbin or toilet. However, some participants reported that while at school, they throw the material in the black bag or bin provided in the toilet, or just on the ground in the toilet. . 


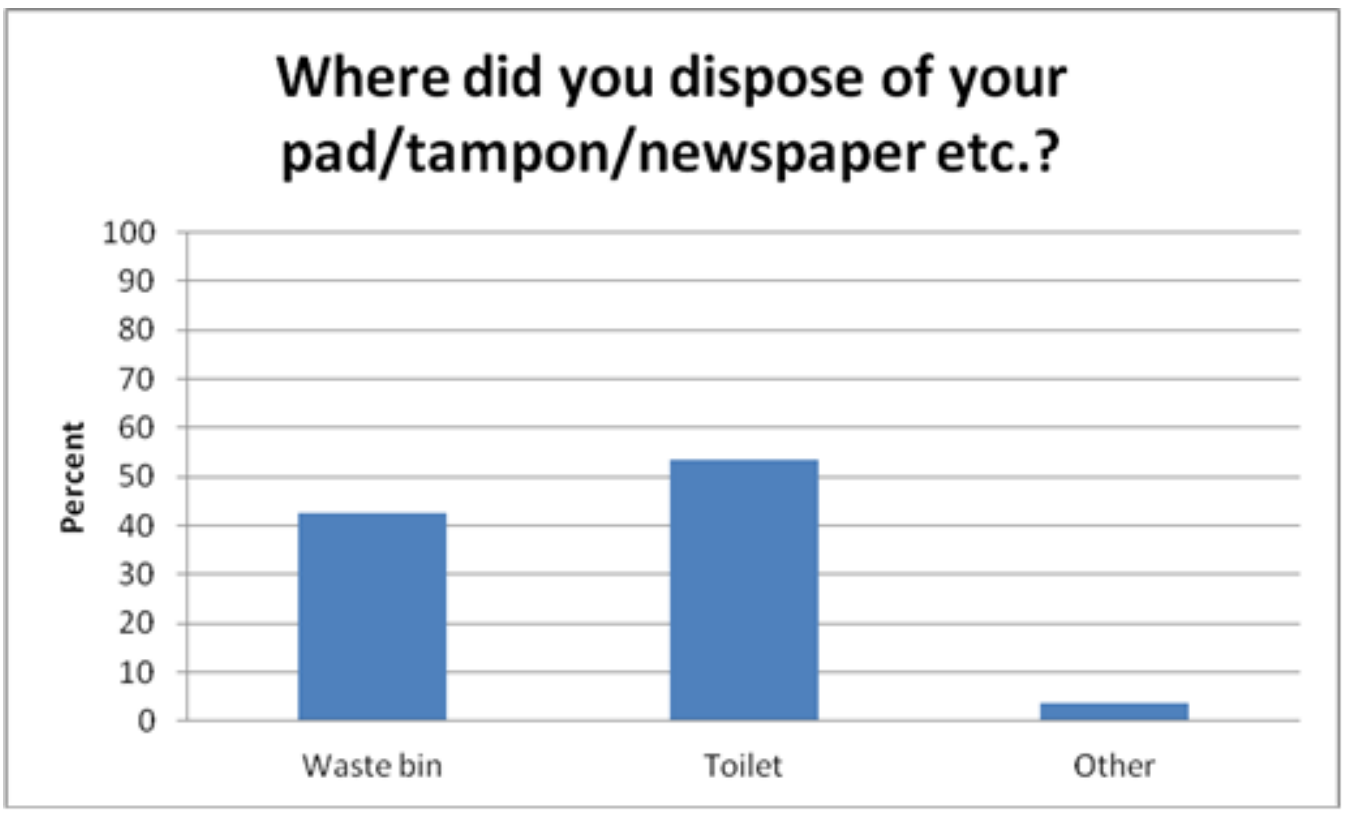

Figure 4: Means of Disposal of Absorbent Material

School Attendance, Participation and Menstruation

The majority of the respondents indicated that they attend school during their menstruation while $29.7 \%$ skip school. The majority $(67.7 \%)$ of respondents, who reported that they missed school during their menstruation, indicated that they skip school for a period of between one to three days.

$29.7 \%$ of the respondents reported being absent from school during menstruation for more than 3 days of school per month during their menses. Studies elsewhere in South Africa indicated that about $30 \%$ girl learners miss school during their menstruation and that on average, about 4 days per month are lost, which adds up to 528 days of schooling that a girls should be in school (WRC 20I I;
DWCPD, 20I3). This figure of $29.7 \%$ of the respondents missing school during menstruation in this study, is slightly lower than that reported in South Africa and elsewhere such as Malawi (I-3 days) (Pillitter, 20I I), Kenya (I.66 days) (Wilson et al., 20I2), Uganda (3-5 days) (Kanyike \& Karungi, 2005), Ghana (3-5 days (Montgomery et al., 20I2). This study established that that even if the girls manage to attend school during menstruation, the pain, headache and fatigue, the fear of staining their clothes and being ridiculed by other learners, reduces their concentration and makes them reluctant to participate in class. In studies conducted in Kenya Malawi and Uganda girl learners reported similar experiences (Croft \& Fischer, 2012; Pillitteri, 20II; Wilson, 20I2). 


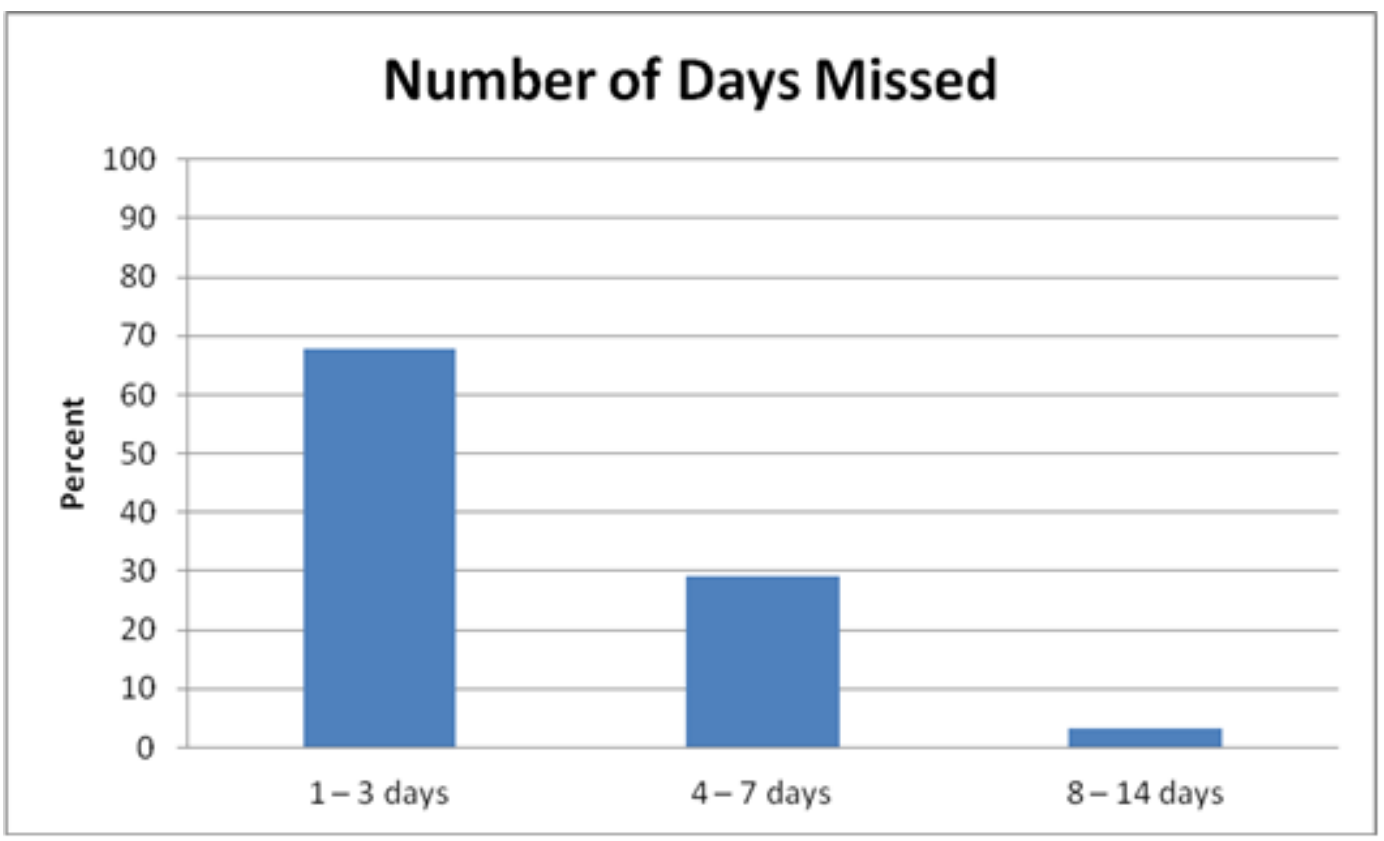

Figure 5: Number of Days Absent From School per Month

The state of the sanitary facilities at schools

In order to effectively manage menstruation hygiene, it is essential that girl learners have access to adequate sanitation at school. The learners need a safe, private space to change used sanitary materials; clean water for washing their hands and facilities for safely disposing used sanitary materials. An inspection of facilities at the 10 schools revealed that at most schools the sanitary facilities are inadequate and unsatisfactory. The facilities were characterized by the following: a lack of privacy, and to varying degrees dysfunctional flush toilets, dysfunctional hand wash basins, broken faucets and a lack of closed disposal bins for the disposal of used sanitary material, dirty and smelly toilets and toilet cubicles that cannot be locked from inside. At some schools, some toilets do not have doors. Only two schools had clean toilets and sanitary facilities. Studies conducted elsewhere also confirm that a lack of sanitary facilities for menstruation hygiene discourage girls from effectively participating in school activities (Fernandes, 2008; MacMahon, 20II; WaterAid, 2009; WRC, 20II). These studies show that inadequate sanitary facilities and sanitary protection may make girl learners uncomfortable in the classroom and unable to participate in class activities. Significant literature and research indicate also that girl learners' school attendance may be significantly increased simply by improving the basic facilities required for dignified menstrual hygiene 
management at school (Mitchell, 2009; Sommer, 2009).

\section{Conclusion}

The findings identified a knowledge deficit on MHM amongst girl learners as well as a mismatch between the knowledge base of the girl learners and the information reportedly provided in schools by educators and passed on by parents. The lack of knowledge about MHM and inadequate sanitary facilities at school contribute to school absenteeism, ineffective MHM practices, and feelings of discomfort among school girls.

The majority of girl school learners face challenges during their menstruation at school. The main challenges were the lack of information on $\mathrm{MHM}$, inadequate sanitary facilities at most schools and a lack of disposal facilities. In addition, most educators do not only lack knowledge about girls' menstrual needs, but are also reluctant to engage with this crucial issue, since they consider MHM to be a taboo subject. As a result, there are challenges that need to be addressed before good MHM can become a reality at the 10 schools covered by the survey.

\section{Recommendations}

In order to overcome the challenges faced by girl learners in managing their menses, the study makes the following recommendations:

- Mothers and female relations play a vital role in transmitting information and knowledge on menstruation, strategies should therefore be developed to improve communication between parents and learners. Consequently, parents and guardians should be trained through workshops, to empower them to impart adequate, correct and appropriate knowledge on puberty.

- In order to address the information and knowledge deficit on puberty, MHM, reproductive health and sexuality, MHM should be integrated into the school curriculum.

- In order to ensure that girl learners can privately and safely manage their menses, all schools should provide adequate and appropriate sanitary facilities for changing, washing, management of menstrual waste, as well as offer privacy and dignity to menstruating girl learners.

\section{Acknowledgement:}

I am grateful for the invaluable financial support given by the Transnet Foundation - Health, South Africa, to conduct this study.

\section{References}

Abioye-Kuteyi,E 2000. "Menstrual knowledge and practices amongst secondary school girls in lle Ife, Nigeria." The Journal of the Royal Society for the Promotion of Health $120: 23$.

Adika, V.O., Yagba, J., Apiyanteide, A.F., Ologidi, P.W. \& Ekpo, K.E 20II. Perception and behavior on use of sanitary pads during menstruation 
among adolescent school girls in Bayelsa State, Nigeria. Adv. Appl. Sci. Res, 2, (6), 9- I5.

Adinma, E.D. \& Adinma, J.I.B 2008. Perceptions and Practices on Menstruation Amongst Nigerian Secondary School Girls. Afr Report Health I2(I): 74-83.

Ali, T.S. \& Rizvi, S.N 2010. Menstrual knowledge and practices of female adolescents in urban Karachi, Pakistan. Journal of Adolescence, 33(4): 531541.

Bharadwaj, S. \& Patkar, A 2004. Menstrual hygiene and management in developing countries: Taking stock. Mumbai, India. Junction Social 23. Available at: http://www.mum.org/menhydev.htm (accessed 9 August 2014)

Croft, T. \& Fisher, J 20I2. Menstrual hygiene in Ugandan schools: an investigation of low-cost sanitary pads. Journal of Water, Sanitation and Hygiene for Development, 2,(I): 50 58.

Dasgupta, A. \& Sarkar, M 2008. Menstrual Hygiene: How Hygienic is the Adolescent Girl? Indian Journal of Community Medicine: Official Publication of Indian Association of Preventive \& Social Medicine, 33,(2): 77-80.

Department of Women, Children and People with Disabilities (DSWPD) 2013. Annual Report. Pretoria: DWPD. Drakshayani, D.K. \& Venkata,R.P 1994." A study on menstrual hygiene among rural adolescent girls". Indian J Med Sci. 48,(6): 139-43.

EEPA 2007 Menstrual Hygiene: A Neglected Condition for the Achievement of Several Millennium
Development Goals. Report of the Europe External Policy Advisors. Available

at

http://www.eepa.be/wcm/dmdocumen ts/BGpaper Menstrual-Hygiene.pdf (Accessed 20 September 20I5).

El-Gilany, A.-H., Badawi, K. \& El-Fedawy, $S$ 2005. "Menstrual Hygiene among Adolescent Schoolgirls in Mansoura, Egypt. Reproductive Health Matters, 13,(26): | 47-152.

Fernandes, M. 2008. The Untold Story Menstrual Hygiene: Issues of Awareness and Practices. Paper presented at the 3rd South Asian Conference on Sanitation, Delhi, India, |9-2|.

GAPS \& FAWE Uganda 1999. Gender and primary school. Kampala: FAWE Uganda. Available at http://www. www.eepa.be/wcm/dmdocuments/BG paper_Menstrual-Hygiene.pdf

(Accessed 20 September 2015).

GLAAS 2010. Global Annual Assessment of Sanitation and Drinking-Water. 2010 UN-Water. Available at http://www.unwater.org/downloads/U N-Water_GLAAS_2010_Report.pdf (Accessed I 3 September 20I4).

House.S., $\quad$ Mahon,T.,Cavill,S. 2012. Menstrual hygiene matters. A resource for improving menstrual hygiene around the world. London: WaterAid.Available at http://www.wateraid.org/what\%20we \%20do/our\%20approach/research\%2 0and\%20publications/view\%20publica tion?id=02309d73-8e4 I-4d04-b2ef664If66I6a4f (Accessed 5 August 2013).

Jasper, C., Le, T.-T. \& Bartram, J 2012. Water and Sanitation in Schools: A 
Systematic Review of the Health and Educational Outcomes. International Journal of Environmental Research and Public Health, 9(8): 2772-2787.

Kaiser,S 2005. Menstrual Hygiene Management. Available at http://www.sswm.info/content/menstr ual-hygiene-management (Accessed 21 September 2015).

Kanyike, F., Akankwasa, D., Karungi, C 2005. Menstruation as a barrier to gender equality in Uganda, FAWE Uganda chapter, Insight Education. Available at

http://webarchive.nationalarchives.gov. uk/2009032 I I 442 I7/http:/www.id21.0 rg/insights/insights-ed03/insightsissed03-art03.html

(Accessed I September 20|3).

Keerti, J. \& Pravin,Y 20II. A Communitybased Study on menstrual hygiene among adolescent girls - India. Indian Journal on Maternal and Child Health, 13,(3): I-6.

Kuper, A 1982. Wives for Cattle: Bridewealth and Marriage in Southern Africa. London: Routledge \& Kegan Paul.

McMahon, S.A., Winch, P.J., Caruso, B.A., Obure, A.F., Ogutu, E.A., Ochari, I.A. \& Rheingans, R.D 20II. The girl with her period is the one to hang her head. Reflections on menstrual management among schoolgirls in rural Kenya. BMC International Health and Human Rights, II,(I): 7. Available at doi: $\quad$ 10.1186/1472-698X-II-7 (Accessed I 3 September 20I4).

Mitchell, C 2009. Geographies of Danger: School Toilets in Sub-Saharan Africa. In Olga Gershenson and Barbara Penner (eds) Ladies and Gents: Public Toilets and Gender. . Philadelphia, PA, Temple University Press, pp. 62-74.

Montgomery, P., Ryus, C.R., Dolan, C.S., Dopson, S. \& Scott, L.M 2012. Sanitary Pad Interventions for Girls' Education in Ghana: A Pilot Study. PLoS ONE, 7,(10), e48274. doi: I 0.137|/journal.pone.0048274 (Accessed I 3 September 20I4).

Nagar, S. \& Aimol, R.K 20I I. Knowledge of Adolescents Girls Regarding Menstruation in Tribal Areas of Meghalaya. Stud Tribes Tribals, 8,(I): 27-30.

Nahar, Q. \& Ahmed, R 2006. Addressing special needs of girls challenges in schools. Paper presented at the 2nd South Asian Conference on Sanitation, Islamabad, Pakistan, 2006. Available at http://www.wateraid.org/documents/p lugin_documents/addressing_the speci al needs of girls. pdf (Accessed 9 August 20|4).

Piper-Pilliteri, S20II. School menstrual hygiene management in Malawi: More than toilets. London, UK: WaterAid. Available at http://www.shareresearch.org/Resourc e/Details/menstrualhygienemanagemen t_malawi (Accessed 13 September 2014).

Shanbhag, R.D. Shilpa, R., D'Souza, N., Josphine, P., Singh, J. \& Goud, B.R 2012. Perceptions Regarding Menstruation and Practices during Menstrual Cycle Among High School Adolescent Girls in Resource Limited Setting Around Bangalore City Karnataka, India. International Journal of Collaborative Research on Internal Medicine \& Public Health 4,(7): I353-1362. 
Save the Children 2015.Give the Girls the Freedom to Live. Available at http://www.savethechildren.org.za/UM MP (Accessed I 3 December 2015).

SNV. 20I5. Factsheet: Girls in Control. Available at http://www.snvworld.org/en/regions/af rica/publications/factsheet-girls-incontrol (Accessed I 3 December 2015). Sommer. M 2008. Menstruation and School Attendance in Sub-Saharan Africa. Girls' Experiences of Menstruation and Schooling in Urban and Rural Kilimanjaro, in Northern Tanzania. Available at http://2008youthconference.blogspot.c om/2008/04/menstruation-and-schoolattendance.htm (Accessed 9 August 20|4).

Sommer, M. 2009. Ideologies of sexuality, menstruation and risk: girls; experiences of puberty and schooling in northern Tanzania. Culture, Health \&amp; Sexuality, I I (4): 383-398.

Sommer,M 2010. "Where the education system and women's bodies collide: The social and health impact of girls' experiences of menstruation and schooling in Tanzania". Journal of Adolescence, 33,(4), 52I-529.

Sommer,M 201I. "An Early Window of Opportunity for Promoting Girls' Health: Policy Implications of the Girl's Puberty Book Project in Tanzania" International Electronic Journal of Health Education, 14 ,77-92.

Sangonet 2015."No Pads No school: Girls Education Going down the Drain.Available at http://www.ngopulse.org/opportunity/ save-children-south-africa-health- promoting-schools-network-facilitator (Accessed I4 December 2015).

StatSA 2010. Millennium Development Goals (MDGs): Country Report 2010. Pretoria, StatSA.

Ten, V.T.A. 2007. Menstrual Hygiene: A Neglected Condition for the Achievement of Several Millennium Development Goals. Europe External Policy Advisors. Available at http://www.eepa.be/wcm/dmdocumen ts/BGpaper Menstrual-Hygiene.pdf (Accessed 9 August 2014).

Transnet Foundation. 2013. Giving the girls the Dignity they Deserve.Available at http://www.transnetfoundation.co.za/ .../health.../giving-girls-the-dignitythey- deserve.pdf (Accessed 20 September 2015).

Udjo, E.O and Lalthapersad - Pillay, P 2015 "Assessing the Achievement of the Millennium Development Goals in Southern Africa”. Africa. Population Studies, 29,(I) |460 - |47|

UNEFPA 2000.The state of the World's Adolescents. New York: UNEFPA.

UNICEF 2005. Sanitation: the challenge. Available at http://www.childinfo.org/areas/ sanitation/ (Accessed 9 August 2013). UNICEF 2010. Raising clean hands: advancing learning, health and participation through WASH in schools, UNICEF, New York. Available at http://www.unicef.org/media/files/raisingcl eanhands_2010.pdf (Accessed 9 August 2013).

WaterAid. 2009. Is Menstrual Hygiene And Management An Issue For Adolescent Girls? A Comparative Study of Four Schools In Different Settings of Nepal. WaterAid in Nepal. , Available at 
http://www.indiahabitat.org/qefl/link/Pr actices/wa_nep_mhm_rep_march2009 .pdf (Accessed 9 August 2014).

WaterAid. 2012. Menstrual Hygiene Matters: A Resource for Improving Menstrual Hygiene Management Around the World. WaterAid, United Kingdom.

WEDC 2014. Developing Knowledge and Capacity in Water and Sanitaion. Menstrual Hygiene Management for School Girls, WEDC, Loughborough University.

WHO 20I0. Developing Guidelines for Water, Sanitation and Hygiene Promotion in Schools. World Health Organization, India. Available at http://www.searo.who.int/LinkFiles/SD E EH-566.pdf (accessed 9 August 2013).

WHO \& UNICEF. 2013. Joint Monitoring Programme for Water Supply and Sanitation. Available at http://www.wssinfo.org//fileadmin/user _upload/resources/MENSTRUALHYGIENE-MANAGEMENT-Paperfor-END-group-I.pdf (Accessed 9 August 2014).

WHO and UNICEF 2013b. Progress on sanitation and drinking-water - 2013 update. Geneva, WHO.Available at http://www.who.int/water sanitation health/publications/2013/jmp report/e $\mathrm{n} /($ Accessed I 4 December 20I5)

WRC 20I I. Dialogue: Menstrual Hygiene Management. Supporting the Sanitary Dignity Campaign for Women and Girls. Water Research Commission. Available at http://www.ecosanres.org/pdf files/Me nstrualHygieneManagementWorkshop
ReportApril2011.pdf (Accessed 13 September 2014). Wilson.E.F.,Reeve,J.M.K.,Pitt,A.H.,Sully,B. G. \& Julious,S.A. 2012. "Pilot study: evaluating the acceptability and short term effect of teaching Kenyan school girls to make reusable sanitary towels on absenteeism and other daily activities: A partial preference parallel group, cluster randomised control trial." School of Health and Related Research (ScHARR), University of Sheffield 27 (20I2).

World Bank 2005. Toolkit on Hygiene Sanitation \& Water in Schools: Gender Roles and Impact. Available athttp://www.wsp.org/Hygiene-

Sanitation-Water-

Toolkit/BasicPrinciples/GenderRoles.ht $\mathrm{ml}$ (Accessed I4 December2015)

WRC 201I. Dialogue: Menstrual Health Management Report April 201I. Department for Women, Children and People with Disabilities, Stockholm Environment Institute and the Water Information Network South Africa. Pretoria: Water Research Commission. WRC 201I. Dialogue: Menstrual Health Management Report April 201I, Department for Women, Children and People with Disabilities, Stockholm Environment Institute and the Water Information Network South Africa. Pretoria: Water Research Commission. Yates, J.S 2004. Doing Social Science Research. London: Sage. 